\title{
QUAN LA JUSTÍCIA ÉS VENJANÇA, CONTRA UN JUEU ${ }^{1}$
}

\author{
WHEN JUSTICE IS VENGEANCE, AGAINST A JEW
}

\author{
FERRAN GARCIA-OLIVER \\ Universitat de València
}

\begin{abstract}
Resum: La mort d'un nen de sis anys, a la València de 1380, desferma odis i temors. Un jueu és acusat d'haver-li llançat una pedrada des de la finestra de casa seua. D'immediat, el justícia criminal obre el procés i amb una rapidesa sorprenent, en menys de tres mesos, pronuncia la sentencia. L'acusació, la defensa i els testimonis proporcionen un breu però formidable fresc de la vida dels sectors subalterns, en torn dels valors, la sociabilitat i les solidaritats, les arrels inestables i les sempre difícils relacions entre jueus i cristians.
\end{abstract}

Paraules clau: justícia; urbanisme; jueus; peritatge mèdic; violència.

\begin{abstract}
In Valencia, in the year 1380, the death of a child aged six unleashes hatred and fear. A Jewish man is accused of throwing a stone at him from his window. The Criminal Justice immediately opens a suit against him and, with amazing speed, pronounces sentence in less than three months. The prosecution, the defence and the witnesses provide a short but splendid picture of the lives of subordinate people in the lower classes, a picture that speaks of values, sociability and solidarity, unsteady roots and the always delicate relationship between Jews and Christians.
\end{abstract}

Keywords: justice; urbanization; Jews; medical expertise; violence.

\section{SUMARI}

1. Els fets immediats.- 2. Mossé Tudelli i Salomó Arroti en un veïnat inestable i mestís.- 3. Dos sastres diligents.- 4. Accions desesperades.-5. El procés.- 6. Turments i sentència.- 7 . Bibliografia citada.

Aquell matí del 24 de març de 1380, vespra de Pasqua, al carrer de Fabra i els seus entorns l'enrenou feiner d'un barri menestral compassa, com tots els dies, el pols quotidià de la ciutat de València. Encara són vistents els estralls de l'apedregada contra la jueria del dia abans, però tothom

1 Abreviatures utilitzades: AMV = Arxiu Municipal de València; ARV = Arxiu del Regne de València. 
anhela ja que la celebració festiva de l'endemà pose fi als rigors dilatats de la Quaresma i a les exacerbacions espirituals de la Setmana Santa. Pasquala, la dona de Francesc Ariet, és a la porta de casa, ligant e fahent dinades de lenya, com lo pare d'ella (...) sia tender e tingua venderia de pa, oli, carbó, lenya e altres coses. Ben a prop, a l'església de Sant Tomàs, el justícia criminal, els notaris Lluís de Menargues i Bartomeu de Vilalba, entre altres, ouen lo offici divinal. Francesca, la dona de Pere Rabassa, ha entrat així mateix dins la esgleya de Sent Thomàs per hoir lo ofici. És un matí ventós, propi del mes març, tant que en molts lochs de la ciutat, e senyaladament en lo dit carrer-de Fabra-feya caure pedres e troses de les teulades dels terrats e de les parets. A la jueria, per ser el sabbat, ningú no hi treballa. Mossé Tudelli i Salomó Arroti són, per part seua, en la sinagoga per oració, i en acabar les pregàries tornen a casa a dinar. Periconet, el fill de Pere Esteve, el flequer de la plaça de la Figuera, ha eixit a jugar cap a l'hora tèrcia, l'hora de missa solta, abans que les gents se dinassen ${ }^{2}$. Tomasa, la mossa de tretze anys del corretger Puigmitjà, es creua amb ell anant a cercar pa al forn prop Sent Johan del Spital. No té més que sis anys Periconet, i si el seu pare no l'ha afermat amb cap altre artesà i campa a lloure pel carrer, doncs, és perquè més prompte que tard s'iniciarà, si és que no ho ha fet ja, en l'ofici de la fleca. Vestit de blau... anava jugant ... ab un gocet, menant-lo ab una corda al coll, tal com los fadrins fan, per les cases del dit pare seu, ço és, per lo carrer de la juheria appellat de Sent Thomàs, qui va a Sent Johan del Espital al cantó de les cases del honrat en Guillem Siscar ${ }^{3}$. De sobte, uns crits de dolor, seguits per uns plors, criden l'atenció de veïns i vianants. Periconet ha caigut estès a terra, $a b$ gran scampament de sanch. Algun objecte contundent ha impactat en el seu cap. N'hi ha que asseguren que el projectil ha caigut sobtadament de la teulada de la casa on viuen llogats Mossé Tudelli i Salomó Arroti. D'altres, en canvi, afirmen que un dels dos llogaters ha tret el braç i ha llançat una pedra contra el fadrí. El pobre Periconet mor al cap d'uns dies. El justícia criminal de seguida pren cartes en l'assumpte, engega una investigació i conclou el procés amb una rapidesa sorprenent, gens habitual en els procediments de la cort. La mort d'un nen innocent sempre és contemplat com una tragèdia terrible. Més encara si presumptament al darrere hi ha la mà, mai millor dit, d'un jueu.

\footnotetext{
2 Cal entendre ací l'hora tèrcia, doncs, l'espai de temps entre les 9 i les 12, entre tèrcia i sexta.

3 Llegiu el carrer de Fabra, que aboca al de Sant Tomàs, la via principal que dóna nom per extensió als altres més petits i secundaris.
} 


\section{ELS FETS IMMEDIATS}

Almenys tres persones contemplen el sinistre i no reaccionen a l'instant com caldria esperar. No ho fan perquè ni per la indumentària ni per la figura resulta impossible discernir si Periconet és jueu o cristià. I perquè la sang, producte d'un accident fortuït i sobretot producte de la violència, és habitual en qualsevol ciutat gòtica ${ }^{4}$. En aquell moment fatal Joana, que viu a la plaça de la Figuera, travessa el carrer de Fabra en direcció a Sant Joan de l'Hospital. Ja a la fi del carrer, tomba la mirada i repara en un nen que juga amb un gosset, lo qual tenia lo cap enclinat devers terra e stant endret de les cases o finestres de Mossé Tudelli i Salomó Aroti ço és, endret una finestra migancera que és vers Sant Johan de l'Spital'. Està convençuda que un d'aquests dos ha tret el braç i ha tirat una pedra, que impacta en el cap del nen. En caure a terra, per comptes d'anar a socórrer-lo, se acostà a una bona tendera, qui stà en lo carrer... e dix-li: "Digau, dona, ¿e és crestià aquell fadrí que jau allí?". És llavors quan Pasquala, que també havia vist desplomar-se el xiquet, decideix anar a veure-hi què passa junt amb Joana.

Poc abans Guillem Francesc, un col-lector de la lleuda de Tortosa, acaba d'eixir de casa, al barri de la Xerea, i, venint-se'n per sos afers dins la ciutat, ha passat per Sant Joan de l'Hospital a fer oració. Acabada la plegària, en veure el portal de Sant Joan obert, entra dins València. Es tracta més aviat d'un portalet que aboca directament al carrer de Fabra, ocupat majoritàriament per jueus. A mitjan carrer entropessa amb Periconet i el gos, just quan un jueu o algú li llança mitja rajola al cap. Els crits del fadrí no l'impressionen gens en creure que és un juható, i en lloc d'anar a socórrer-lo havia dit semblants paraules: "Bona la tens!", et no s'agué cura de la fahena. Instants després, les dues dones ja són on Periconet plora. No tenen encara clar la seua filiació religiosa. És per això que Pasquala alçà-li les faldes e guardà aquell en lo menbre. E, veent e coneixent la dita dona flaquera ${ }^{6}$ que lo dit Periconet era cristià..., torquà-li la sanch... e pres aquell als braços e mès-lo dins casa sua, e en aprés mès un tros de drap al dit fadrí en la dita naffra e portà aquell a casa del dit en Pere Stheve, pare d'aquell. Ara qui brama és Pasquala - grans crits cridant- enmig del carrer. Guillem Francesc, el lleuder, que ha omès l'auxili, comprèn que el ferit és un cristià i no pot reprimir la invectiva

4 Per al cas de valencià vegeu P. Pérez Garcia, La comparsa; R. Narbona, Pueblo, i P. Viciano, Violencia.

5 Totes les cites del procés, les anteriors i les que segueixen en Arxiu del Regne de València, Justícia criminal, núm. $75,5^{\mathrm{a}}$ mà, f. 39, i $9^{\mathrm{a}}$ mà, f. 9 . La reconstrucció del succés $1^{\prime}$ he feta utilitzant diversos testimonis del procés, no sempre coincidents del tot ni en la sequiència temporal ni en certs detalls.

6 L'escrivà aquí s'enganya: Pasquala no és "flequera" sinó "tendera". 
contra els jueus que es troba davant seu: $O$, cans! ¿Fills de cristians? ¿E què havets feyt? Que jur en Déu que si lo fadrí me atenyia res axí com no fa... ell los acoltellegaria tots quants estan en les dites cases! L'assumpte comença a oldre malament. Per precaució, els jueus que són al carrer es fan fonedissos.

Tots excepte Mossé Tudelli, un dels llogaters de la casa sota la qual s'ha desplomat Periconet, el qual ha davallat als crits e rumor que en lo dit carrer havia. Francesca, casada amb Domingo Castell, parroquià també de Sant Tomàs, en veure'l, l'aborda d'aquesta guisa: En Mossé, veus que dien que de casa vostra és exida la pedra ab la qual han nafrat lo dit fadrí. Una interpel-lació que indica, d'entrada, un grau de confiança i amistat que depassa els filtres confessionals. La resposta ratifica el grau de coneixença mútua: Mala Pascua me don Déus si yo sé que la dita pedra sia exida de casa mia, car veu que ma muller e mos fills e lo dit Salamó Arroti e sa muller estan e seen sobre taula, que's dinen, e yo hi sehia, e als crits que he hoüt só devallat. Fa la impressió que Mossé Tudelli vol deixar, abans que res, ben clara la innocència de les dues famílies que habiten en la casa, i després saber de primera mà l'abast de la desgràcia, tot i que deu ser conscient que comet una imprudència atesa l'excitació ambiental.

La notícia es difon ràpidament pel veïnat: un jueu ha tirat una pedrada a un fadrinet cristià. Aquesta és la remor que s'escampa com una taca d'oli. Un dels que hi acudeix al lloc dels fets és el corredor Antoni Mateu, que viu al carrer dels Hostals, prop de la plaça de la Figuera. Se n'ha assabentat gràcies a una nina que està en la Corretgeria, ab un bon hom, anomenada Tomasa. Amb la idea sumària del que s'ha esdevingut, partí de aquí e anà yvaçosament a la esgleya de Sent Thomàs al honrat justícia. Els moviments del justícia criminal per la parròquia i els seus costums havien de ser, sens dubte, ben coneguts per tothom. El que notifica al justícia i a més gent no és que un xiquet ha resultat ferit en estranyes circumstàncies, sinó que, com admet Bartomeu Vilalba, el notari i escrivà de la Sala, vench fama en la dita esgleya que juheus havien naffrat un fadrí crestià. Joan de Quintavall, el justícia criminal, va de pressa cap a la casa dels dos jueus, en companyia de quatre saigs, dels notaris Vilalba, Menargues i un munt de curiosos. Just abans de l'arribada del justícia, Mossé Tudelli, després de la conversa amb Francesca, se n'ha pujat dalt a la casa.

Sobta que darrere de l'oficial vinga una colla de veïns i passavolants. Però cap norma ni llei no ho prohibeix, i com el treball dels artesans, la tasca de la justícia ha de fer-se a la llum del dia i en presència de testimonis. En qualsevol cas, la presència de tota aquesta gent amb els ànims escalfats no pot ser més que intimidatòria. Hi entren sense trucar. Jaume Alfons, l'especier de la plaça de la Figuera, veu com Salomó Arroti, dinava ensemps ab sa muller, et axí matex... lo dit Mossé Tudelli, qui stava decantat en la cambra del dit Salomó Arroti sobre 
un lit que y havia. La taula era parada sobre un arquibanch o caxa qui stava en la dita cambra denant la finestra. El justícia els pregunta si havia entrat algú en la dita cambra sinó ells, los quals respongueren e dixeren que no. Però qui pren la paraula a continuació és l'especier i no el justícia, en dir-los a la cara: Donchs que vosaltres que algú no y ha entrat sinó vosaltres en la dita cambra, vosaltres ho haveu fet o sabeu qui ha naffrat e donada la pedrada al cap al dit Periconet. Segons el parer del mateix especier los dits juheus stigueren quaix espantats. No podia ser menys davant l'acusació, la vinguda del justícia i els saigs i tota aquella gent amb cara de pocs amics. No y sé res, que ací me dinava ab ma muller, afirma Salomó Arroti. Però Tomasa, la mossa d'en Puigmitjà, l'assenyala com l'autor de la pedrada, mentre que Guillem Francesc, el lleuder, que també hi és, assegura que ha vist com algú tirava una pedra per aquella finestra de la cambra. El pare de Periconet reclama a Joan de Quintavall que els prenga, et encontinent, lo dit justícia, volent husar de son ofici e vehent que la requesta per lo dit en Pere Stheve era justa, se'ls endú a la presó. No pocs els creuen innocents, en estar convençuts que tot ha estat un accident a causa de la teula caiguda per la força del vent, i per aquesta raó se'n complanyen, excepte alguns fadrins. Mentrestant, Pere Esteve ha dut el fill a casa d'un metge per a la primera cura d'urgència'.

\section{MossÉ Tudelli I SALOMÓ ARROTI EN UN VEÏNAT INESTABLE I MESTÍS}

¿Qui són aquests dos homes que menen cap a la "cadena”? Una parella de sastres que, amb les respectives dones i fills, viuen llogats en casa d'un correligionari anomenat Benvenist lo Parler. Cada família posseeix les seus pròpies cambres, però l'espai disponible necessàriament deu ser minúscul. Tan petit és l'habitatge que ni disposen de taula, i han de fer servir un arquibanc o caixa per a dinar. Mossé cus en un "menjadoret". L'atapeïment de les llars jueves és inevitable. Cap a 1380, la jueria de València ja fa temps que ha desbordat els seus límits fixats per Jaume I. Cada vegada més poblada, pel creixement intern i per la imantació d'immigrants d'altres aljames del regne i de la Corona d'Aragó, i de més enllà encara de les fronteres, ha esgotat l'espai utilitzable per a la construcció de nous immobles. La saturació ja s’aprecia des de 1354 almenys, quan s'ocupen més de vint cases en la veïna parròquia de Sant Andreu ${ }^{8}$. Vint-i-cinc anys més tard la situació ha empitjorat. La zona just

\footnotetext{
7 Francesc és el seu nom: "Et en aprés veu metjar lo dit fadrí en casa d'en Francesch, metge", declara Gabriel Amat, un dels testimonis aportats per Pere Esteve

8 En la visita pastoral efectuada aquest any, un parroquia respon quod in eadem parrochia permixti cum christianis morantur iudeos, qui habent ibi ultra XX hospitia. J. Rodrigo Pertegás: La judería, p. 7.
} 
on viuen Tudelli i Arroti en temps passat solia ésser poblat de cristians e puis era stat ocupat tot per juheus fora les clausures e límits de la lur juheria. El carrer de Fabra, situat prop de la carnisseria jueva, en realitat és un carreró estret i mal ventilat. Dos anys abans, en una sessió del Consell, es va reconèixer

que en la dita ciutat havia diverses carrers, dels quals alcuns en los caps o cantonades o altres partides d'aquells han tanta estretura que sens gran affany e encara perill les gents, e majorment les bèsties de tragí, senyaladament a temps de venemes, no poden bonament pasar per aquells... E d'aquells defalliments foren specialment e expressa per alcuns del dit Consell nomenats lo carrer major de Sent Nicholau, appellat dels Cavallers, per esguart del capdamunt d'aquell, e.l carrer per lo qual partén prop de la ecclèsia de Sent Thomàs va hom a la ecclèsia de Sent Johan del Espital, prop la juheria ${ }^{9}$.

Tothom considera el carrer de Fabra passatge públich e comú de Sent Thomàs a Sent Johan del Spital ${ }^{10}$. Devia córrer paral-lel al carrer de la Mar, fora dels límits de l'antiga jueria, i és ben probable que el seu recorregut fos pres com a referència per al controvertit eixamplament de 1389 per la banda $\operatorname{nord}^{11}$.

9 I no sols dificultava el trànsit sinó que "tornaven... a deformitat de la dita ciutat". Uns deien que el Consell hi devia intervenir, d'altres que no. Finalment es decideix elegir sis prohoms que reconeguen els dits dos carrers, per tal d'adobar-los a despesa dels veïns i de la ciutat. La reunió té lloc el 28 de setembre de 1378. AMV, Manual de Consells, 17, f. 157-157v.

10 Recordem que Guillem Francesc, el lleuder de Tortosa, havia "entrat" a València per Sant Joan de l'Hospital a través d'un portal obert. És a aquest portal al qual es refereix el veguer dels jurats de la ciutat el 13 de febrer de 1388, vuit anys després del procés per la mort de Periconet, en un escrit adreçat al comanador de la casa de Sant Joan de l'Hospital, on li recorda que per anar a Sant Joan "convingués fer gran volta e longa via, o passar per dins les clausures de la dita juheria e entrar en lo pati denant la dita ecclèsia per un postich o portalet poch". ARV, notal de Jaume Mestre, núm. 2.639, f. 19. El 1392, un any després de l'assalt i el pogrom, el rei i la reina encarreguen a misser Domingo Mascó l'enderrocament dels tancaments de la vella i nova jueria projectada tan sols tres anys enrere "axí com lo portal de la Çabateria, que ix vers la plaça de la Figuera, e lo portalet vers Sent Johan del Spital, e lo portalet vers lo bany d'En Splugues e semblants faça enderrocar, en manera que romanguen sens senyal de portal o clausura carrers públichs". J. Hinojosa, En el nombre de Yahveh, p. 434.

${ }_{11}$ El tancament de la jueria planificat el 1388, que devia contemplar el cegament del carreró de Fabra, explicaria, en primer lloc, les queixes de Sant Joan de l'Hospital, per l'expropiació d'una part de l'edifici, i la de tot el barri de la Xerea, particularment del convent de Sant Domènec, perquè romandrien encara més aïllats del centre de la ciutat; i, en segon lloc, la necessitat de convertir un atzucac en carrer -el del Miracle- tot just per facilitar el trànsit en direcció est-oest i viceversa. En el tancament del carrer de Fabra, però sobretot en l'obertura del del Miracle, se sentirà ben perjudicada la casa de l'Hospital. Per fer-lo possible, el veguer i els mestres que l'hi assisteixen prenen "una partida de la albergada de la dita casa, la qual partida era en major part descoberta", amb tot d'edificis "sotils e vells e roïnoses e en major part derrocats, e l'àls dispost a ruïna per lur vetustat, com fossen morischs e de temps de moros". A més, per aconseguir el traçat recte del carrer, prenen també "una cantonada del forn de la dita casa", amb 


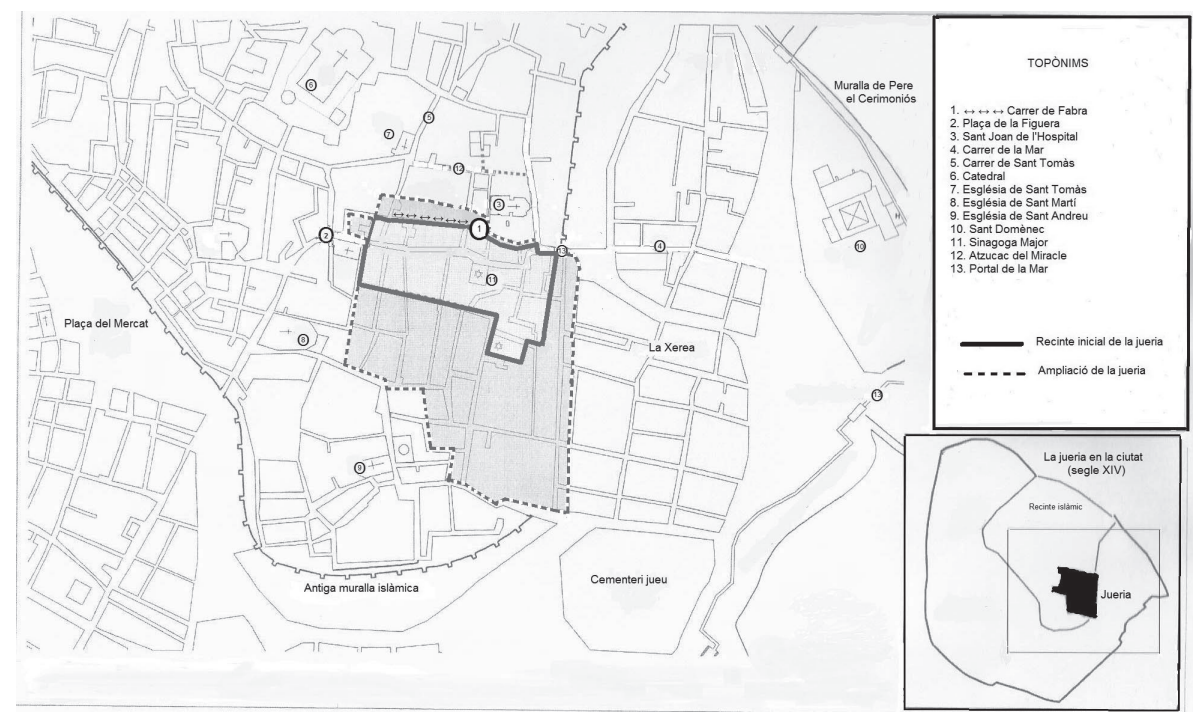

Plànol de la jueria de València i els seus entorns ${ }^{12}$

Per a oprobi dels més estrictes amb les normatives municipals i dels més rigorosos amb els preceptes eclesiàstics, al carrer de Fabra i els seus entorns habiten tot de cristians mesclats ab los dits juheus. Mentre que Pasquala, la tendera, viu amb el seu pare Beneito de Vilanova aprés de les cases de Mossé i Salomó, i Domingo Castell i la seua dona Francesca, atinent, el matrimoni Pere Rabassa i Francesca viuen de front ${ }^{13}$. Protestes per la residència fora dels

l'enderrocament d'un arc del dit forn. A l'hora de refer-lo, el veguer i els mestres d'obres prengueren esment que s'havia d'alçar just "envers o prop" la cambra del prior i les dels preveres. Per a estalviar-los incomoditats, decideixen que el forn "se mudàs e-s refés en altra partida de la dita albergada poch pus amunt del primer forn envers la dita juheria, ço és, a tinent del ort o claustra de la dita casa. E lo dit veguer ab maestres, veents que.1 sòl o espay de aquella partida no bastaria per al dit forn e casa del forner e per a portal e entrada nova, que era e és necessària del dit carrer nou en la dita ecclèsia, si donchs no prenia una partida del dit ort o claustra, per estalviar açò hagué una casa del alberch d'un juheu contigua a la dita partida e aquella casa féu derrocar e allí fer portal e entrada del dit carrer nou en la dita ecclèsia a fi que en la dita partida romangués prou espay o sòl per a fer lo dit forn e casa del forner sens tocar al ort o claustra". L'oposició de l'Hospital és absoluta. El document ja citat (ARV, notal de Jaume Mestre, núm. 2.639, f. 19), amb la posterior resposta de l'Hospital, és una peça important per a la història de l'urbanisme de la ciutat de València.

12 Reelaboració a partir de la base cartogràfica elaborada per E. Dies Cusi per a l'exposició La Máquina del Tiempo del Museu d'Història de València.

13 No són els únics cristians, però. El juponer Francesc Bonfill s'identifica com a resident en un carrer "prop" de Sant Francesc, segurament el de Fabra. 
murs sempre les hi ha hagut, a València i arreu de les ciutats i viles de la Corona d'Aragó. Ara i adés els queixosos esgrimeixen escrúpols espirituals, relatius a la contaminació hebraica. Els prejudicis, tanmateix, emmascaren conflictes i greuges menys vaporosos que els escàndols e perils derivats d'aquesta barre$\mathrm{ja}^{14}$. A la primeria de 1386, sis anys més tard de la mort de Periconet, els rectors de Sant Tomàs i Sant Andreu insistiran en els perjudicis infligits a la fe per raó de la compra de les cases efectuades pels jueus en les seues parròquies. El que els dol, més que res, és la minva d'ingressos en concepte d'obres de caritat, sepultures, almoines i de donacions habituals dels fidels. També Violant de Bar, a qui el seu marit el rei Joan I li ha conferit la senyoria de l'aljama, té motius per a la inquietud un any després, però ara a causa dels cristians que per via tant de préstechs com de logrers es fan amb cases de la jueria. Per tal que les rendes no continuen acusant les pèrdues, exigeix al batle l'expulsió d'aquests especuladors $^{15}$. El tancament del carrer de Fabra i l'obertura simultània de l'atzucac del Miracle es farà, segons els jurats de València, per extirpar e esquivar molts e grans peccats tan enormes que són indignes de relació qui alli.s cometien en gran offensa de Déu e vituperi de la sua sacra ley cristiana. Però, més que pecats, sorgia la incomoditat de fer una gran volta per evitar d'entrar a la jueria pel portalet minúscul situat davant de l'església de l'Hospital,

majorment com als dies de major devoció dels feels cristians, specialment en dits Dijous e Divendres sants de cascun any, on les gents per singular devoció e per grans (...) de la dita ecclèsia fahien e fan a aquella gran romeria no podien passar per lo dit postich, com los portals de la dita jueria fossen e estien tancats en aquells dies ${ }^{16}$

Sempre que els interessos privats o col-lectius no es consideren danyats, la fluïdesa dels contactes es produeix tant dins com fora la jueria. El ban municipal i el sermó de la trona -també el del rabí- s'estampen contra una realitat més flexible que afavoreix una xarxa densa de sociabilitat prohibida. El pare de Periconet mai no li ha negat el pa que Mossé Tudelli li compra de vegades a la porta de $\operatorname{casa}^{17}$.

14 F. Garcia-Oliver, Jueus contra la norma.

15 J. Hinojosa, En nombre de Yahveh, pp. 68 i 262.

16 Rafael Narbona recentment ha analitzat els complexos problemes urbanístics ocasionats per l'ampliació extraordinària de la jueria, és a dir, l'ocupació de iure de l'espai que els jueus havien fet per compres i lloguers. L'oposició als plans per una bona part de ciutadans és un ingredient més no negligible en el desencadenament del pogrom de 1391. R. Narbona, El trienio negro.

17 Mossé Tudelli confessa que "havia comprat pa alcunes de vegades en la plaça de la Figuera de casa del dit en Pere Steve, on tenia venderia de pa". Una asseveració que suggereix 
Mossé no va nàixer a València. És un emigrant castellà, que degué venir de menut amb els seus progenitors quinze o disset anys abans, cap a 1365, de ple en les turbulències de la guerra de Castella ${ }^{18}$. El seu pare almenys encara és viu, però no comparteix amb ell domicili, ja que Mossé viu, amb la seua dona Cristall i dos fills almenys, llogat en la casa del carrer de Fabra, d'ençà a penes sis mesos ${ }^{19}$. Salomó no compta encara amb els crèdits de Mossé, perquè encara és un adolescent: era jove en edat, a vigares d'ella-Tomasa, la mossa de Puigmitjà-de XVI anys, poch més o menys, e que no tenia barba. Ja està casat amb Clara, i sens dubte ell també no deu fer gaire que habita en la casa de Benvenist lo Parler.

Però és que tampoc els cristians no poden exhibir arrels profundes en el barri, si més no la majoria dels qui compareixen com a testimonis del procés. $\mathrm{Al}$ compàs de la guerra passada de Castella, encara present en la consciència dels valencians, les fams, les caresties i les pestes, els desplaçaments continus exacerben la mobilitat usual de les gents. Les declaracions dels trenta-set testimonis del procés revelen amb rotunditat inapel-lable el caràcter inestable de la residència de la majoria d'ells. No hi ha ningú capaç de remuntar la coneixença de Pere Esteve, Mossé Tudelli i Salomó Arroti més enllà dels disset anys, cristià o jueu. El mercader Pasqual de Fons i Jafudà Façan ho exornen amb l'expressió de xiquea ençà, referida a Mossé. Dels vint-i-set testimonis que fan servir una expressió temporal, set la situen entre els deu i els disset anys; altres deu, entre els cinc i els deu anys; sis, entre un i cinc anys; i tres, entre els cinc i sis mesos, mentre un altre -un jueu precisament- és incapaç de recordar des de quan coneix els imputats. Pere Esteve, el flequer, fa cinc anys que viu a la plaça de la Figuera, del any de la fam ençà, puntualitza Pasquala la tendera amb una memòria sacsejada per la que va ser, en el còmput contemporani, la segona gran fam ${ }^{20}$; Tomasa en fa quatre que treballa com a mossa i resideix en casa de l'amo, el corretger Puigmitjà; tres són els que Pere Rabassa i la seua

una restricció de moviments de les dones fora de la jueria, en particular de les més joves. Una restricció, no cap supressió absoluta, com després veurem.

18 Tomasa i Gabriel Amat es refereixen a ell com el jueu "castellà". El mercader Pasqual Fons el coneix "de xiquea ençà", des de disset anys abans, mentre que Francesca, la dona de Pere Desplà, els rebaixa a quinze, però a València i Xàtiva. El sastre Bernat Guerau declara que fa uns vuit anys que el coneix i que "l'ha vist talar en la ciutat de Xàtiva a mossèn Guillem de Bellvís diverses robes". Els testimonis i les circumstàncies conviden a pensar, doncs, que Mossé Tudelli arribà de Castella sent un nen, en companyia dels seus progenitors. En el si domèstic o afermat amb un mestre, aprendria l'ofici de sastre. La seua perícia i ambició l'ha dut a desplaçar-se fins a Xàtiva a treballar, on cal no descartar una residència temporal. El 1380, devia tenir en torn dels trenta anys.

19 Segons el testimoni acreditat del sastre Ramon Rovira, el qual afirma que Tudelli, en efecte, viu "de mig any ençà en unes cases situades en un carrer on stan juheus prop Sent Thomàs".

20 El temps precisament que coneix Pere Esteve, el pare de Periconet. 
dona Francesca resideixen al carrer de Fabra, dos i mig més que el matrimoni Domingo Castell i Francesca i que els mateixos Mossé Tudelli i Salomó Arroti. I Jafudà Façan, per bé que el coneix des de la infantesa, i a Salomó de dos anys enrere, s'ha posat a viure al carrer de Fabra també sols mig any abans.

Taula 1: La "memòria" dels testimonis

\begin{tabular}{|c|c|c|c|c|}
\hline Nom & Ofici & Residència & Veïnatge & Temps \\
\hline Pasqual de Fons & Mercader & & Ciutadà & $\begin{array}{c}17 \text { anys } \\
\text { "de xiquea ençà" }\end{array}$ \\
\hline Jafudà Façan & & & - & "de xiquea ençà" \\
\hline Pere Desplà & Juponer & & Ciutadà & 15 anys \\
\hline $\begin{array}{c}\text { Francesca, dona } \\
\text { de } \\
\text { Pere Desplà }\end{array}$ & & & - & 15 anys \\
\hline Francesc Bonfill & Juponer & & Veí & 15 anys \\
\hline Bartomeu Roig & Sastre & & Ciutadà & 10 anys \\
\hline Gabriel Amat & Escolà & $\begin{array}{l}\text { Carrer de les } \\
\text { Avellanes }\end{array}$ & Habitant & 10 anys \\
\hline Bernat Guerau & Escriptor & & Veí & 8 anys \\
\hline $\begin{array}{l}\text { Abraham de } \\
\text { Carcassona }\end{array}$ & & & - & 8 anys \\
\hline $\begin{array}{l}\text { Joana, dona de } \\
\text { Joan Garcia, } \\
\text { llaurador }\end{array}$ & & $\begin{array}{l}\text { Plaça de la } \\
\text { Figuera }\end{array}$ & $\begin{array}{c}\text { Comorant } \\
\text { a } \\
\text { Carraixet }\end{array}$ & 8 anys \\
\hline $\begin{array}{l}\text { Benvinguda, dona } \\
\text { de Guillem Llonc }\end{array}$ & & & - & 8 anys \\
\hline Guillem Llonc & Sastre & & Ciutadà & 8 anys \\
\hline $\begin{array}{l}\text { Marquesa, dona } \\
\text { d'Esteve Franciac }\end{array}$ & (Saboner) & & (Ciutadà) & 7 anys \\
\hline Domingo Castell & Correu & Carrer de Fabra & Veí & $\begin{array}{c}6 \text { anys } \\
\text { (sis mesos que viu } \\
\text { al carrer) }\end{array}$ \\
\hline Joan Borràs & Corredor & & Veí & 6 anys \\
\hline $\begin{array}{l}\text { Pasquala, dona de } \\
\text { Francesc Arriet, } \\
\text { mestre d'aixa }\end{array}$ & Tendera & Carrer de Fabra & Veïna & 5 anys \\
\hline Abraam Aziz & & & - & 5 anys \\
\hline
\end{tabular}




\begin{tabular}{|c|c|c|c|c|}
\hline Bernat Malet & Generós & & Habitador & 4 anys \\
\hline Tomasa & Mossa & Portal del Teixó & - & 4 anys \\
\hline Pere Rabassa & & Carrer de Fabra & Veí & 2 anys \\
\hline $\begin{array}{l}\text { Bondia, dona } \\
\text { de Francesc de } \\
\text { Santmartí, }\end{array}$ & (Llaurador) & & Veïna & $\begin{array}{l}2 \text { anys: "lonch } \\
\text { temps" }\end{array}$ \\
\hline $\begin{array}{l}\text { Beneito de } \\
\text { Vilanova }\end{array}$ & Tender & & Veí & $\begin{array}{c}1 \text { any } \\
\text { (2 anys, en un } \\
\text { segon testimoni) }\end{array}$ \\
\hline Joan Borràs & Peller & $\begin{array}{l}\text { Plaça de } \\
\text { l'Herba }\end{array}$ & Ciutadà & 1 any \\
\hline $\begin{array}{c}\text { Francesca, dona } \\
\text { de Domingo } \\
\text { Castell }\end{array}$ & & Carrer de Fabra & Veïna & $\begin{array}{l}6 \text { mesos que } \\
\text { habita al carrer }\end{array}$ \\
\hline $\begin{array}{l}\text { Marieta, dona de } \\
\text { Ramon Bolea }\end{array}$ & (Teixidor) & & Veïna & 6 mesos \\
\hline $\begin{array}{l}\text { Violant, dona de } \\
\text { Joan Garcés }\end{array}$ & (Moliner) & & Veïna & 5 mesos \\
\hline Jucef Cohen & & & - & No ho recorda \\
\hline Guillem Francesc & & La Xerea & Comorant & \\
\hline $\begin{array}{c}\text { Suau, dona de } \\
\text { Domingo Sanç }\end{array}$ & (Mariner) & La Xerea & Veïna & - \\
\hline $\begin{array}{l}\text { Francesca, dona } \\
\text { de Pere Rabassa }\end{array}$ & & & Veïna & - \\
\hline $\begin{array}{c}\text { Lluís de } \\
\text { Menargues }\end{array}$ & Notari & $\begin{array}{l}\text { (parròquia de } \\
\text { Sant Tomàs) }\end{array}$ & Ciutadà & - \\
\hline $\begin{array}{c}\text { Bartomeu de } \\
\text { Vilalba }\end{array}$ & Notari & $\begin{array}{l}\text { Parròquia de } \\
\text { Sant Tomàs }\end{array}$ & Ciutadà & - \\
\hline Jaume Alfons & Especier & $\begin{array}{c}\text { Plaça de la } \\
\text { Figuera }\end{array}$ & Veí & - \\
\hline Antoni Mateu & Corredor & $\begin{array}{l}\text { Carrer dels } \\
\text { Hostals }\end{array}$ & Veí & - \\
\hline Arnau de Pisa & & & Veí & - \\
\hline Pere Escrivà & Cirurgià & $\begin{array}{l}\text { Prop del bany } \\
\text { de la Plaça de } \\
\text { la Figuera }\end{array}$ & Veí & - \\
\hline Ramon Rovira & Sastre & & Ciutadà & - \\
\hline
\end{tabular}


Aquesta mirada concentrada sobre una zona concreta de la ciutat de València, la que pivota entorn de la plaça de la Figuera, té el valor suplementari de corroborar la constant i imponent mobilitat de la población ${ }^{21}$. Aquí resideix per damunt de tot un component menestral, gent dels oficis. No deixa de ser simptomàtic que només un generós comparega davant de la cort del justícia per donar el seu testimoni: Bernat Malet, qualificat d'habitador ${ }^{22}$. Com també és revelador que el titular d'una memòria més densa siga un ciutadà, el mercader Pasqual de Fons, i que altres dos ciutadans, els notaris Vilalba i Menargues, per altres referències sabem de la seua dilatada permanència en la parròquia de Sant Tomàs ${ }^{23}$. La resta fa la impressió d'arrelaments precaris, de canvis intermitents de domicili, d'estades temporals, a la recerca d'una quimèrica estabilitat garantida pel treball i el matrimoni. Joana es defineix com a comorant del lloc de Carraixet, on s'ha casat amb el llaurador Joan Garcia, però s'és criada e nodrida en la plaça de la Figuera, on té casa. La circulació va en ambdós sentits, cap a dins i fora de la ciutat. Ara bé, la topografia de València, amb les seues dotze parròquies i els ravals extramurs, conforma un territori abonat per als desplaçaments. Pere Esteve ha obert la fleca fa cinc anys a la plaça de la Figuera, però els uns i els altres el coneixen de molt abans ${ }^{24}$. Fins la mateixa jueria és un microcosmos inestable, com dóna a entendre els sis mesos que Isaac Façan, Mossé Tudelli i Salomó Arroti tenen nou domicili al carrer de Fabra.

La inconsistència de les arrels i el trànsit intermitent es tradueix en la feblesa dels lligams d'amistat i coneixença mútua. I això, en un jueu, sota un clima permanent de desconfiança que en moments puntuals tomba

21 A. Furió, F. Garcia-Oliver, The horitzons; G. Navarro, Política.

22 Els Malet són un llinatge amb llarga i fonda radicació a la parròquia de Sant Tomàs. El seu pare ha estat conseller elet per la parròquia de Sant Tomàs deu vegades entre 1321 i 1361, mentre que ell ho és també, però dels cavallers i generosos, sis vegades entre 1372 i 1384; és candidat a jurat el 1371, jurat pels cavallers el 1378 i 1383 i justícia criminal el 1385. Bernat Malet és el personatge de més polític que testimonia en el procés. Dec aquestes dades a la cortesia de Rafael Narbona.

23 Vilalba ha estat elet conseller per la parròquia de Sant Tomàs, si més no, el 1366. A Bartomeu de Vilalba el coneixen sobretot per ser l'escrivà de la Sala del Consell des de 1371, i ho continuarà sent fins 1399 , després de vint-i-vuit anys de treballs amb la ploma i deixar el rastre inesborrable d'una prosa competent, més enllà de les rutines burocràtiques. El seu domicili el té al mateix carrer de Sant Tomàs. En un document del 26 d'agost de 1388 es parla, en efecte, del "carrer de Sent Thomàs, davant lo alberch o cases del discret en Berthomeu Vilalba": ARV, protocols de Francesc Monsó, núm. 1.550. Sobre Bartomeu de Vilalba i la seua tasca gràcies a la qual proporcionà a l'escrivania de la ciutat uns dels seus moments més fecunds, materialment i qualitativament, vegeu A. Rubio, L'escrivania. Menargues, l'altre notari, serà precisament qui durà els comptes del tancament de la jueria el 1390. J. Rodrigo Pertegás, La judería, p. 9.

${ }^{24} \mathrm{Al}$ seu torn, per exemple, Domingo Castell fa sols sis mesos que viu al carrer de Fabra, però sis anys anys que coneix Pere Esteve, és a dir, que feia sols mig any que s'hi havia traslladat des d'un altre punt de la ciutat. 
cap a l'hostilitat oberta, no pot jugar sinó en contra. Perquè, precisament, davant d'una acusació tan perillosa com la d'haver llançat una pedra a una criatura cristiana, cal demostrar i argumentar amb proves i fets una bona conducta, l'honorabilitat, la bona vida, fama e conversació. En aquesta batalla per la reputació, Salomó Arroti parteix amb un notori desavantatge: és jove i, doncs, sense els vincles de complicitat que proporciona l'edat, el matrimoni amb fills i la pluralitat de contactes proporcionats per l'antiguitat en l'ofici.

\section{Taula 2: Els crèdits temporals de Mossé i Salomó}

\begin{tabular}{|c|c|c|}
\hline & Mossé Tudelli & Salomó Arroti \\
\hline Pasqual de Fons, mercader & 17 anys & No el coneix \\
\hline Jafudà Façan & "de xiquea ençà" & 2 anys \\
\hline Pere Desplà, juponer & 15 anys & 3 mesos \\
\hline Francesca, dona de Pere Desplà & 15 anys & No el coneix \\
\hline Francesc Bonfill, juponer & 15 anys & No el coneix \\
\hline Bartomeu Roig, sastre & 10 anys & No el coneix \\
\hline Beneito de Vilanova & 2 anys & 2 anys \\
\hline Bernat Guerau, escriptor & 8 anys & 10 mesos \\
\hline Benvinguda & 8 anys & 2 anys \\
\hline Guillem Llonc, sastre & 8 anys & 2 anys \\
\hline Joan Borràs, corredor & 6 anys & No el coneix \\
\hline Abraham Aziz & 5 anys & 4 anys \\
\hline Na Bondia & No el coneix & 2 anys: "lonch temps" \\
\hline Joan Borràs, peller & 1 any & 1 any \\
\hline Abraham de Carcassona & 1 any & 8 anys \\
\hline $\begin{array}{l}\text { Francesca, dona de Domingo } \\
\text { Castell }\end{array}$ & 6 mesos & 6 mesos \\
\hline Domingo Castell & 6 mesos & 6 mesos \\
\hline Ramon Rovira, sastre & 6 mesos & No el coneix \\
\hline Na Marieta & 6 mesos & - \\
\hline $\mathrm{Na}$ Violant & 5 mesos & - \\
\hline Jucef Cohen & No ho recorda & No ho recorda \\
\hline Bernat Malet & No el coneix & 4 anys \\
\hline $\mathrm{Na}$ Marquesa & - & 7 anys \\
\hline
\end{tabular}


Tots aquests vint-i-tres testimonis són aportats per Bartomeu Cerdà, com a procurador dels dos acusats ${ }^{25}$. El balanç és demolidor per a Salomó Arroti. Sis no el coneixen i quatre no arriben ni a l'any. El testimoniatge dels qui situen la coneixença -dos jueus i dos cristians- per damunt dels quatre anys desconcerta a la vista dels qui avalen Mossé Tudelli. ¿Com és possible que Abraham de Carcassona faça vuit anys que coneix Salomó i un de sol Mossé, en una aljama on necessàriament els uns saben dels altres? ¿Per què na Marquesa acredita set anys per a Salomó i silencia Mossé, i na Bondia assegura que no coneix aquest i sí l'altre de lonch temps... abans que lo dit fill seu ne prengués muller, ben dos anys? Seria massa rebuscat pensar que tots quatre -Salomó, Abraham, na Marquesa i na Bondia- són recents immigrants d'un mateix lloc on, abans de venir a València, entaularen coneixença. Més aviat sembla una argúcia de la defensa, tramada pel procurador Bartomeu Cerdà, per a capgirar la situació desesperada de Salomó Arroti. Hi ha sospites raonables -però només són sospites- que fan recelar de la veritat absoluta d'alguns testimoniatges. Dit d'una altra manera: no es pot descartar que algú s'haja deixat untar per diners dels amics de Salomó. L'escolà Gabriel Amat, germà menut del notari Guillem, ha oït de moltes persones que després que Pasquala, la tendera, agafés Periconet per dur-lo a casa i fer-li la primera cura, encontinent devallà de les cases dels dits juheus una juhia, muller del un dels dits juheus, e que se'n era entrada rebenta en casa de la dita na Pascuala e que havia donat diners a la dita na Pascuala la dita juhia, e que la pregava que no digués que de la finestra de les cases dels dits juheus fos stada la dita pedra. La brama s'escampa perquè Pere Escrivà, el segon metge que atén Periconet, també se'n fa ressò, en el sentit que els dos denunciats havien promeses donar un florí d'or a una dona tendera que està en lo carrer... per tal que no digués que ells havien lançada la dita pedra, ni digués d'on era venguda ni d'on com aquella ho hagués vist bé de cert. Si és veritat aquest tracte -per una suma ridícula, per a la gravetat del que encara era una ferida en el cap d'un infant cristià-, Pasquala s'ha abstingut, per descomptat, d'esmentar-ho en la seua confessió, com també ha evitat repetir el que va dir a la seua comare Francesca, la dona de Domingo Castell: que la pedra, en efecte, havia estat llançada des de la casa de Mossé i Salomó.

Bartomeu Cerdà, el procurador dels acusats, no rebat la presumpta compra del testimoni de Pasquala, ni el justícia hi indaga més a fons inexplicablement, però també cal remarcar que pel que fa a Gabriel Amat la seua animadversió envers Salomó resulta manifesta. Una vegada es van barallar

25 El notari Pere Llàtzer, com a procurador de Pere Esteve, s'ha ocupat, en canvi, dels crèdits temporals del seu patrocinat. 
al carrer, i la seua declaració destillla la rancúnia de l'enemic. Un dia que no recorda, diu Amat,

venia de la vinya de son germà, e, passant per la juheria e prop la carnisseria dels jueus, ell... veu un juheu dels dits denunciats, emperò no era lo castellà ans era l'altre, calcigava e tenia entre peus e feria a un fadrí fort xich crestià, e que, ferint aquell, lo dit juheu li dehia al dit fadrí: "Perro, fill de perro".

En veure que Salomó Arroti malmenava lo dit fadrí, Amat l'ajudà per tal que no.l consumàs. El mateix insult de perro, fill de perro el repeteix contra ell. L'insult -la injúria- provocà que Amat li donés un gran colp al dit juheu. Com que Arroti s'hi tornà, Amat

havia trahit lo punyal per deffendre's del dit juheu. E que lo dit
juheu se'n era entrat en una casa et trach un punyal en la mà e
lexàs córrer a ell..., que si no fos per allcuns juheus qui conexien
a ell..., que lo juheu lo hagra mort a ell..., sinó que aquells lo y
contrastaven.

Una freqüent baralla d'adolescents esdevé ara, en boca d'un Gabriel Amat ressentit, una ocasió per a perfilar l'esbós d'una conducta assassina. La pedrada contra Periconet no és fruit d'un tràgic accident sinó el corol-lari d'una maldat anunciada, vol donar a entendre l'escolà. Pere Rabassa hi afegeix més llenya al foc, assegurant que era ver que un dels dits juheus, ço és, lo pus jove, és mala persona e hom de la fama e condició... per ço com ell... havia vist al dit juheu barallar ab diverses fadrins cristians e venint corrent detràs aquells per ferir-los.

Entenguem aquestes refregues com brots de la profunditat i extensió dels contactes entre jueus i cristians, en aquest cas de joves que aprofiten qualsevol avinentesa per a posar a prova la virilitat i les ardències que els dispara l'agressivitat pròpia de l'edat. No es tracta de cap de les maneres d'episodis de lluita entre jueus i cristians. Sens dubte, el rerefons de les dues religions rivals cal no negligir-lo, però els desencadenants obeeixen a uns patrons culturals on la violència es respira pertot arreu, des de la mètrica poètica fins a la decoració de les cases, des de la ficció literària als exempla dels predicadors, des dels jocs fins als desbordaments de la fe passats pel sedàs del ritual i des de les argúcies de l'amor fins a l'administració de la justícia. Només que Rabassa per raons que ignorem, però que segurament insinuen una relació tibant amb Salomó Arroti producte d'una topada anterior, vol ara accentuar la inclinació del "jueu" a barallar-se i perseguir fadrins crestians per fer-los mal. 


\section{DOS SASTRES DILIGENTS}

El retrat, tanmateix, que confeccionen els testimonis aportats per Bartomeu Cerdà capgira per complet la imatge malèvola dels inculpats. Mossé i Salomó són sastres i usen de offici de sastreria ab lurs mullers. Normalment treballen a casa, i sovint els veïns els troben en lo carrer fahent sa fahena. A vegades, però, Mossé es trasllada a la cambra de Salomó a cosir perquè és pus clara per la finestra que ix a la carrera. Cerdà insisteix que són diligents e curosos en son ofici, et procuren tant com poden cascun dia que sia en ells de haver fahenes et guanyant justament a obs de la vida, axí ab cristians com juheus en lo dit lur ofici honestament e simpla. L'elogi previsible del procurador el corrobora extensament el juponer Pere Desplà. Ell ha lliurat a Mossé Tudelli diverses vegades costures, e era gran obrer e bon menestral, que no.l podia fartar de costures e veya que aquell tallava bé totes coses e no.l podia ell... fartar de fahena, tanta fahena fahia axí de nit com de dia. I ho sap perquè ha longuament usat e praticat amb ell. De Salomó Arroti, tanmateix, no pot certificar si és tant procurant com Mossé Tudelli, com no haja tant privat aquell com lo dit Mossé. Això no obstant, s'afanya a dir que tant l'un com l'altre tallen e cusen e fan lurs fahenes dins lur alberch, cascuns en ses cambres, sens que no fan ni dient mal a ningú, ans veu que aquells, fahén sa obra..., són avinents en lur ofici e corteses a les gents, fahents e dients bé per ço que sien ben volguts. Francesca, la dona de Desplà, hi afegeix el detall ben revelador que Mossé Tudelli en algunes ocasions ha treballat en casa del matrimoni, saltant, doncs, la prohibició que jueus entren en habitació de cristians, o que cristians acullen jueus als seus domicilis, en un afany de guanyar diners honestament que el fa anar de corcoll de casa en casa: hoc encara, que se'n anava a casa sua si algú havia demanat per tallar alguna cosa. E vehia que lo fill del dit Mossé lo venia a demanar, dient-li que a casa lo demanaven per tallar alguna cosa, e lo dit Mossé, volent abarcar molta fahena, anava per talar a casa sua. Bernat Malet, tot un conseller de la parròquia representant dels cavallers i generosos, és pràcticament l'únic que lloa Salomó. Aconseguir la seua compareixença és mèrit de Bartomeu Cerdà, sens dubte. Ningú com un Malet per avalar l'honradesa del jove Arroti. Però les paraules que pronuncia són un calc de la defensa, com passa amb totes les confessions decebedores dels jueus, que no gosen eixir del guió confegit per Cerdà: és diligent e curós en lur ofici, e procura tant com pot que en ell sia de haver fahenes e guanyant justament a obs de la vida lur, axí ab cristians com ab juheus, en lo dit lur ofici honestament e simpla.

Els sastres hebreus estan en el punt de mira dels seus col-legues cristians. No sols compten amb una cartera de clients entre els seus correligionaris, sinó que contínuament són sol-licitats de fora de la jueria. Des fa set o vuit 
anys el sastre Bartomeu Roig ha tramès en lo dit carrer-de Fabra-diverses fadrins, los quals staven ab ell... qui a botoneres que li fahien botons, qui al dit Mossé e altres juheus qui tenien robes sues per a cosir. El recurs a aquesta mà d'obra femenina, i així mateix masculina, no pot ser degut més que a la demanda de salaris i retribucions menors i l'oferta de productes a preus més mòdics ${ }^{26}$. A l'abaratiment dels preus s'afegeix la invasió del territori urbà antany habitat per cristians. El maig de 1391, dos mesos abans del pogrom, els majorals de l'ofici elevaran una protesta als nous jurats pels prejudicis causats pels sastres jueus, per haver eixit fora del seu barri i ocupar carrers adjacents, amb el suport del batle general i d'alcuns grans hòmens ${ }^{27}$.

¿Qui millor, però, que els sastres per a avalar la professionalitat dels acusats? Tudelli sovint ha cosit a costures, és a dir, a destall, per a Bartomeu Roig, Guillem Llonc i Bartomeu Rovira, i els tres han pogut comprovar que era e és bon menestral e hom leal e vertader. Aquest últim en particular hi afegeix que per la sua lealtat li fiava casa sua axí com fos crestià. De fet, poc abans de la Setmana Santa, havia acabat unes robes que Rovira havia tallat per al tresorer d'Alfons el Vell, marquès de Villena i comte de Dénia, i de les quals costures no ha molt que... n'à pagat al dit juheu. Mossé i Salomó també han treballat per a pellers com Joan Borràs, el qual los ha donat roba e nova que $\cdot l l . .$. comprà en la plaça de la Erba per adobar. A part reben nombrosos encàrrecs directament, sense les mediacions dels sastres cristians. Violant, dona del moliner Joan Garcés i mossa de Jaume Rigolf, i Marieta, la dona del teixidor Ramon de Bolea, s'i anaren lo dia de Pascua proppassada per lo matí a casa del dit Mossé Tudelli per una samarreta que aquell fahia a la filla del dit Jacme Rigolf. Altres vegades són ells mateixos qui es desplacen a les cases dels cristians. És el que féu Salomó en la de Bondia per cosir ab en Guillem de

26 D. Bramon, Contra moros, p. 66.

27 El descontentament venia de molt més abans, no cal dir-ho. En una sessió del Consell de l' 1 de febrer de 1386, es discutí tant del lloguer que feien sastres jueus de taules i obradors "en diverses partides de la ciutat", com dels "salaris immoderats" que els sastres cristians els demanaven. Per tal com, doncs, "se podien seguir alcuns inconvenients e dans", el Consell resol que els jurats i advocats de la ciutat "se certifiquen de tot açò en fer e examinen entre si què o qual cosa parrà sobre los dits affers mellor o pus expedient al dit Consell leguda e possible de fer, e facen-ne relació en altre Consell perquè hi puxa millor proveir". AMV, Manual de Consells, A 18, f. 119v. El 1397, tornen a sorgir "inconvenients", ara entre els cristians vells, representats pels "bons de l'ofici" i els conversos. El rebuig es basava ara en raons fiscals. R. Narbona, Pueblo, p. 54. L'animadversió derivada de la competència jueva depassa l'ofici dels sastres i es detecta arreu dels centres urbans de la Corona d'Aragó. L'endemà dels pogroms de $1391 \mathrm{els}$ oficis instaran mesures per entrebancar quan no impossibilitar el treball dels conversos i dels jueus sobrevivents. A Perpinyà, els menestrals pressionaran el batle perquè publique, el 27 de juny de 1427, una ordenació que prohibia donar cap faena als menestrals jueus, com ara sastres, sabaters o giponers. La gravetat de la mesura obligà fins i tot Alfons el Magnànim a revocar-lo, conscient que la privació del treball conduïa els jueus a morir de fam i que era injust i intolerable que un cristià no pogués "donar roba vella per cosir als jueus". P. Vidal, Els jueus, pp. 56-57. 
Sentmartí, fill d'ella... abans que lo dit fill seu ne pregués muller ben dos anys. Aquestes comandes contínues, a l'una i altra banda del call, es tradueixen en beneficis fefaents. El mercader Pasqual de Fons afirma que Tudelli ha cusit e fet fahenes ab ell... e ell... li taxà diverses robes que lo dit Mossé Tudelli féu a.n Guerau Domènech, vehín de Alco, de què hac ben XIIII liures reals de València de costures ${ }^{28}$.

\section{ACCIONS DESESPERADES}

Mentre Periconet viurà, les esperances de Mossé Tudelli i Salomó Arroti romanen intactes. Si es restableix, tot es reduirà a una simple pena pecuniària. Els clams a causa de ferides provocades per pedres no són rars en els tribunals, dins i fora de la jueria, i es resolen mitjançant composicions monetàries, variables en funció de la gravetat del dany i de la solvència del culpable. Allò cert és que cal moure ràpidament tots els ressorts possibles, ben pocs, tot siga dit, per aconseguir l'alliberament dels inculpats o bé reforçar-ne la innocència. La rapidesa i espontaneïtat amb què Clara o Cristall, segurament Clara, ha anat a oferir-li diners a Pasquala perquè s'estiga de dir que la pedra fou llançada de dins la casa-sempre que això siga veritat-, revela tant la consciència immediata del perill per la situació creada i que se l'ha de conjurar si cal recorrent al suborn, com també la més que probable pràctica habitual de la compra del silenci mitjançant unes monedes per a evitar el rigor de la justícia.

Més difícil es presenta aturar les ganes de revenja dels cristians, significativament dels joves. Mossos, macips i fadrins, els mateixos que han intervingut en l'harca del Divendres Sant, volen avançar-se a l'acció de la justícia. Dilluns de Pasqua tornen a tirar pedres, des del carrer i des dels terrats. La dona de Domingo Castell, Francesca, veu tirar a cristians moltes e diverses pedres a les cases dels juheus, tantes qu.ella... no.s gosava fer a la sua porta, dients los dits cristians apedregants: "Als perros qui han nafrat lo dit fadrí, a ells!", o semblants paraules. Pere Desplà, el juponer, de pas pel carrer de Fabra, i advertit pels veïns jueus que li deien Guara, guara, sènyer, que per los terrats tiren..., se hach apartat vora la paret e mès la mà a un broquer que portava e mès-lo al cap, que sinó lo hagren nafrat a ell. Francesca, la dona de Domingo Castell, que es dirigeix cap a Sant Joan de l'Hospital, recrimina a dos mossos, que s'està d'identificar, perquè volent fer mal a algun jueu el fan als cristians que volen travessar el carrer de Fabra. No s'hi pot passar de cap manera i, doncs, per temor de les pedres que tiraven, axí los dos moços com

28 El topònim “Alco", no l'he pogut trobar. És una lectura dubtosa. 
altres, pres altre camí e anà a la dita església de Sent Johan del Spital per la carniceria nova. Les autoritats municipals hi deixen fer. Ja els va bé que la violència es limite a bandes de joves, prenga la forma del ritual del Divendres Sant i no es desborde en aldarulls incontrolables.

Les dones de Mossé i Salomó, que de moment resten a casa, tenen motius per a l'esverament. Més Clara que Cristall, perquè des que el justícia ha pujat a casa d'elles, les quatre persones que diuen que ho han vist tot-Guillem Francesc, el collidor de la lleuda de Tortosa, Gabriel Amat, l'escolà, Joana, la dona del llaurador Joan Garcia i Tomasa, la mosseta d'en Puigmitjà- assenyalen cap a un agressor més jove, morè, sense barba i vestint robes que només poden ser de Salomó. Joan de Quintavall els empresona preventivament perquè dóna més credibilitat a les paraules d'uns cristians que als al·legats d'una parella de jueus atemorits; també pel fet de ser jueus i el damnificat un infant. El procediment acostumat en aquests casos, en canvi, devia haver requerit la presentació d'un clam formal davant la cort del justícia per comptes de procedir en base a una presumpció, que no és compartida per tots els veïns de la contrada: cap dels quatre acusadors viuen al carrer de Fabra.

Davant el tomb perillós que de seguida han pres els esdeveniments, Clara intenta una acció desesperada, atesa la seua triple condició de dona, jove i jueva: anar a casa de Guillem Francesc, el lleuder. Però, per a una hebrea, menor de vint anys pel que sembla, traspassar sola les portes de la jueria deu comportar massa riscs. Cap correligionari seu no l'hi acompanya. Dissabte, l'endemà d'un Divendres Sant sempre conflictiu, l'excitació dels cristians ha revifat amb la notícia de l'agressió a un menut de la plaça de la Figuera. És una temeritat eixir de la jueria. Vet ací que Joan Borràs, un peller de la plaça de l'Herba, situada just enfront de la porta dels Apòstols de la catedral, va cap a l'hora de vespres a casa de Salomó a recollir unes robes que li havia donades a tallar e cosir. Borràs, després de dir-li Clara que son marit havien mès en la cadena et que no podia donar recapte de les dites robes, es presta a acompanyar-la a pregàries de la dita juhia, fins a la Xerea, a un hom lo qual la dita juhia havia mester. Francesc Guillem no hi és. Na Suau, la dona del mariner Domingo Sanç, que viu davant de la casa del lleuder, pregunta a Clara la raó per la qual el demana, i li contesta perquè li fes testimoni de veritat. Cap a l'hora de vespres, quan té lloc aquest encontre, na Suau ja sap el que ha passat pel matí a la parròquia de Sant Tomàs per boca del mateix lleuder, i no s'està d'abordar-la amb aquestes paraules: Et què, na juhia, ¿és ton marit aquell juheu que ha mort lo fadrí crestià que diu en Francesch Guillem? En poques hores els fets s'han deformat, i ja es parla de la mort de Periconet. Clara, indignada, replica dient-li que no era mort lo dit fadrí e que mala ventura era stada de son marit, que stant a la finestra li havia scapada una pedra que tenia en la mà, que podia pesar tro a dues onces, e que havia donat al dit fadrí en lo cap. 
La versió, però, d'aquesta mateixa trobada i fugaç conversa donada per Pere Llàtzer, el procurador de Pere Esteve, emfasitza la vilesa de Salomó i les males i secretes arts de la seua dona per a encobrir-lo. Llàtzer reprodueix així el diàleg entre Clara i Suau:

\begin{abstract}
“Dona, ¿sabríets on és aquest hom, en Guillem Francesch?”. La dita na Suau dix: "No u sé. ¿A què.l vols?". La dita juhia dix fort secretament: "Dona, yo.l volia que no fes ço que fer poria en lo feyt de la pedreta que fon tirada al fill de flaquer de la plaça de la Figuera, que mala ventura fon de mon marit que li scapà la pedra de la mà stant a la finestra, la qual dita pedra no pesava dues onces".
\end{abstract}

O Clara és una ingènua bocamoll, inconscient de la transcendència d'aquesta revelació, o na Suau menteix. Clara, durant la instrucció del procés, a pregunta del justícia si el que havia confessat na Suau era veritat, respondrà que no, salvu que era anada al dit en Francesch Guillem que li fes saber la dita fahena testimoni de veritat, e que altres paraules no y havia dites ${ }^{29}$.

Pocs dies després Cristall i Clara són empresonades. La salut de Periconet ha empitjorat. Ara l'ajuda envers els dos matrimonis procedeix del pare de Mossé Tudelli, qui deu fer-se càrrec dels néts. La seua també és una acció desesperada, executada per mitjà del sastre Jucef Esperill ${ }^{30}$. Ha de demanar a Pere Escrivà, cirurgià, que dessospite el xiquet. La dessospitació només es feia quan, passat un cert temps prudencial, es presumia que el ferit estava fora de sospita, quan ja no hi havia perill per a la seua vida. Es tracta, doncs, tan sols d'un pronòstic efectuat per un metge competent ${ }^{31}$. És un procediment habitual en les corts del justícia i té per objectiu sovint l'alliberament de l'inculpat sota caplleuta, o garantia donada per un tercer de respondre per ell tothora que serà demanat pel tribunal. La dessospitació de Periconet, sol-licitada pel pare de Mossé Tudelli busca, més aviat, d'alliberar les dones, no el seu fill i Salomó, convençut que ambdós es troben més segurs en la presó. Escrivà, el metge, requerit com a testimoni pel procurador de Pere Esteve, declara que afectuosament, Esperill li va dir:

29 A Joan Borràs, que hi era present, tanmateix, no li ho preguntarà. Caritativament, de la mateixa manera que havia acompanyat Clara fins a la Xerea, la durà de nou a la jueria: "com no.l trobassen -el lleuder-, que se'n eren tornats a casa del dit juheu", diu en la seua confessió.

30 D'Esperill sabem que fou objecte d'un furt de robes per part de Mossé Abado. El cristià Joan Bruguera féu la fiança al lladre. J. Hinojosa, La comunidad, pp. 70-71.

31 El recurs al metge en els processos criminals per a efectuar dictàmens i peritatges data de la fi del segle XIII. A la Corona d'Aragó han estat estudiades per M.R. McVaugh, Medicine, pp. 207-209. Vegeu també de M. Gallent, Precedentes. Al País Valencià entren en la legislació foral el 1329, per bé que aquests procediments són anteriors, probablement des de l'endemà de la conquesta. C. Ferragud, El naixement, pp. 101-102. 
Sènyer en Pere, prega-us lo pare de Mossé Tudelli e yo, sènyer, semblantment vos en prech per amor de Déu, qui sus pot fer en tot cas, que vós desospitàsseu lo dit Periconet de la naffra del cap per tal que.s donen a caplevar la muller del dit Mossé Tudelli e del dit Salomó Arroti, com sien fembres e n'ajam pietat, que sos marits, donchs que són hòmens, no·s ha cura, que mils staran ells en la presó que no estaran elles.

Pere Escrivà, cautelós, prefereix deixar passar uns dies i actuar en funció de l'evolució del nen: En juheu, lo fadrí està mal e yo no.l poria desospitar. Emperò, lexau passar uns IIII o V dies e serà millorada la cura, e veurem en quina disposició estarà o no. El pare de Mossé, no satisfet per la demora, insisteix en la demanda. L'endemà, gran matí, abans que $l l-P e r e$ Escrivà-... fos levat, Esperill es presenta a casa seua i li fa saber: Sènyer en Pere, diu lo pare del dit Mossé Tudelli que aneu a regonèxer e visitar lo dit fadrí del dit colp, que diu que no y enviaria altri metge per mà de desospitar lo dit fadri $^{32}$. Esteve finalment hi accedeix. Després que l'ach guardat torna a casa seua i a la porta es troba Bartomeu Alfonso, l'especier de la plaça de la Figuera, i els metges Pere Soler i Jaume d'Avinyó. En Pere -li diuen-, nosaltres ha estona que us speram, e que volem visitar aquex fadrí per veure si.s porà desospitar o no. No hi indiquen qui els hi ha enviat, però tal com es desprèn de l'acusació de Pere Llàtzer, ha estat a instància també del pare de Tudelli, ateses les reserves de Pere Escrivà: Et axí matex, han request et instat que altre metge reconegués et tingués en cura aquell dit Periconet esemps ab lo metge que ja tenia aquell en cura $^{33}$. Avinyó no és un metge qualsevol. Protegit de la casa reial, compta amb més antipaties que simpaties al municipi. Involucrat en bregues de bàndols, participa contínuament en peritatges i dessospitacions. És un personatge temible, i les paraules d'Escrivà prou que ho donen a entendre:

Sapiats que yo he guardat la nafra del dit fadrí e ha-us decebut, axí lo pare del dit Mossé Tudelli qui $\cdot \mathrm{m}$ havia tramès a dir que guardàs e vesitàs lo dit fadrí, com d'aquests IIII o V dies no y entenia a trametre negun metge per mà de desospitar lo dit fadrí, per veritat no us voldria fer tal descortesia. Emperò, yo us mostraré lo juheu qui dix les dites coses per tal que no us pensets que yo ho faça per malvolença.

32 Tot un detall revelador, dit siga de passada, de les preferències i percepcions que hom tenia dels practicants de la medicina. El pare de Tudelli només es fia de Pere Escrivà.

33 Llàtzer, que aprofita qualsevol excusa per a incidir en la perversitat de Mossé i Salomó, indica al tribunal que el fet d'haver reclamat la dessospitació és una prova concloent de la culpabilitat d'un dels dos jueus, tot i que Jucef Espirell li ho havia demanat a Pere Escrivà per tal de poder capllevar Clara i Cristall. 
Si s'ha avançat, hi al-lega Escrivà davant d'aquests dos metges de més prestigi -i poder-, és sols per la voluntat del seu pacient, no per descortesia ${ }^{34}$.

\section{EL PROCÉS}

El menut, finalment, stant malalt e en poder de metge, de la dita nafra és mort e passat de aquesta present vida en l'altra. Pere Escrivà no ha pogut fer res per salvar-lo. La crispació torna a aflorar. Al carrer de Fabra van algunes persones ajustades, moltes de les quals se dehia que venien de soterrar lo dit Periconet. Divendres 13 d'abril, vint dies després del desastre, Pere Esteve, el seu pare, presenta la denúncia davant la cort del justícia ${ }^{35}$. Amb un matís suplementari: per a perfilar la personalitat malèvola dels jueus en la capitulació acusatòria, deixa anar que no sols llançaren la pedra que impactà al cap del seu fill, sinó que aquell dissabte, vespra de Pasqua, en vilipendi de la festa dels cristians... los dits juheus eo l'altre de aquells, en la dita ora, ans e pres, foren vists tirar o lançar pedres e rajolles per la dita finestra als crestians qui per casa staven e passaven, e açò moltes e diverses vegades. Després de desglossar l'acusació en deu capítols, Esteve demana al justícia la corresponent investigació -inquisició- per a trobar la veritat dels fets i l'aplicació de les penes contemplades als Furs de València, a fi que siguen a altres càstich, terror et exempli volents semblants crims o d'altre cometre e assajar. El pare de Periconet es compromet durant la instrucció del procés a no eixir fora la terra del rei, la qual ha daçà la mar, sense llicència de la cort sota la pena de cent morabatins d'or.

Efectuada la preceptiva obligació, el justícia, aquest mateix dia, trau de la presó els inculpats per rebre les primeres confessions secretament e apartada, davant la presència de misser Miquel Just, el seu assessor ordinari, i l'escrivà. Aquells neguen les imputacions. El justícia no les fa públiques fins dilluns, tres dies després, perquè abans vol rebre les de Cristall i Clara, també en secret $i$ a part. Després de les confessions de tots quatre, el justícia, a instància dels acusats, mana a Pere Esteve que en el termini de cinc dies aje produït e donat dels millors testimonis que produir e donar vulla per a fonamentar les acusacions. El dia 24, Pere Esteve, ara ja per mitjà del notari i procurador seu Pere Llàtzer, tracta de desmuntar les confessions dels inculpats per discordes i hi afegeix nous capítols -rahons, judicis, conjectures et addicions-, sobre

\footnotetext{
34 Sobre Jaume Avinyó veieu de C. Ferragud, El metge.

35 Sobre aquest tribunal veieu de R. Narbona, El justícia criminal; F. Roca Traver, El justicia de Valencia.
} 
els quals seran interrogats els dos matrimonis al cap de tres dies, i com en la primera ocasió insisteixen en la seua innocència ${ }^{36}$. El mateix dia 24, a hora de vespres, Bartomeu Cerdà, com a procurador dels denunciats, articula la defensa per mitjà de vint-i-un capítols. Conclosa l'exposició, Cerdà demana que els quatre acusats siguen donats a caplleuta, com segons fur, algú que sia acusat de qualsevol crim, per gran que sie, no deja ésser mès en carcre ni en presó donant covinent capllevador de la sua persona. El justícia no atén la petició, $i$ en canvi li concedeix deu dies per a provar la defensa ${ }^{37}$. Des de l'anterior dia 17, però, havia començat la roda de testimonis aportats per l'acusació, que són publicats el 5 de maig. Els de Pere Llàtzer, rebuts entre el 17 i el 30 d'abril, en sumen divuit, cinc dels quals són dones i un, l'escolà Gabriel Amat, repeteix dues vegades, atesa la transcendència de la seua confessió ${ }^{38}$. En tres dies només, entre el 27 i 30 d'abril, Bartomeu Cerdà havia fet comparèixer tots els seus: vint-i-quatre, amb vuit dones, quatre hebreus i el testimoni dues vegades repetit del peller Joan Borràs. A sis noms se'ls demana declarar tant l'acusació com la defensa: Francesca, dona de Pere Desplà, Pasquala, la tendera, Domingo Castell i la seua dona Francesca, Beneito de Vilanova, pastor, i Joan Borràs ${ }^{39}$.

Pere Llàtzer ordena l'acusació sobre dos arguments. L'un, escassament convincent, postula que tots dos són homes de mala vida, fama i conversació. L'altre, decisiu, parteix del fet que diversos vianants veieren un home tirar una pedra des de la finestra -la pus xicha- on viuen justament Mossé Tudelli i Salomó Arroti. Ningú més que ells hi havia en la casa en el moment que la llançaren ¿Qui ho veié? Doncs Guillem Francesc, Gabriel Amat, Joana, i Tomasa, la resta se n'assabentaren per d'altres de diferents maneres. Fins i tot són capaços de descriure la indumentària que duia l'agressor i alguns trets físics remarcables. Certament el lleuder dubta quin dels dos ha estat, emperò

36 Una altra vegada el justícia, a requesta dels acusats, atorga a Pere Esteve deu dies "de prova a provar axí los capítols de la dita denunciació com les dites rahons e judicis aprés de aquella proposats".

37 No hi ha cap negativa expressa de la caplleuta, però el silenci de Joan de Quintavall i els fets posteriors així ho indiquen.

${ }_{38}$ Per ordre d'aparició: Pasquala, Francesca, dona de Pere Desplà, Francesca, dona de Domingo Castell, Guillem Francesc, Beneito de Vilanova, Gabriel Amat, Joana, dona de Joan Garcia, Domingo Castell, Pere Rabassa, Tomasa, Suau, dona de Domingo Sanç, Joan Borràs, Gabriel Amat de nou, Lluís de Menargues, Bartomeu Vilalba, Jaume Alfons, Antoni Mateu, Arnau de Pisa i Pere Escrivà.

39 Per ordre d'aparició: Pere Desplà, Francesca, dona de Pere Desplà, Francesca, dona de Domingo Castell, Domingo Castell, Beneito de Vilanova, Pasquala, Francesc Bonfill, Bernat Malet, Ramon Rovira, Pasqual de Fons, Bartomeu Roig, Violant, dona de Joan Garcés, Marieta, dona de Ramon de Bolea, Bernat Guerau, Joan Borràs, Guillem Llonc, Benvinguda, dona de Guillem Llonc, Bondia, dona de Francesc de Santmartí, Jafudà Façan, Jucef Cohen, Abraham de Carcassona, Abraham Aziz, Marquesa, dona d'Esteve Franciac i Joan Borràs de nou. 
que li era vijares que lo braç fon treyt per la finestra e lançà la dita pedra fos de persona lora o naraïna, és a dir, de pell fosca; l'escolà hi afegeix que aquest braç tenia mànega burella, ab una pedra en la mà... emperò no era lo castellà, ans era l'altre, i la serventa, que el qui s'acostà a la finestra estava menjant, era un jove d'uns setze anys, sense barba i jueu -Tomasa, doncs, devia tenir un ull prodigiós per a clissar jueus de lluny i pel buc estret d'una finestra-, ab la cara larga naray, lo qual tenia en lo cap un capiró de drap blau clar..., lo qual tragué lo cap e lo braç per la dita finestra ab una pedra en la mà e tirà aquella al dit Periconet... E que decontinent que lo dit juheu hach lançada la dita pedra al dit fadrí se'n era entrat. D'altra banda, exposa Pere Llàtzer, quan una de les mullers -Clara, el més probable-, hoí cridar una dona dient que de la dita finestra havien tramesa la dita pedra, promès donar a aquella, e lo y donava de feyt, un florí. Des d'un primer moment han volgut comprar el silenci dels testimonis. Atès, per altra banda, que han acudit a metges per demanar-los la dessospitació del nen, tot i el seu estat greu, prova que un d'ells el va ferir:

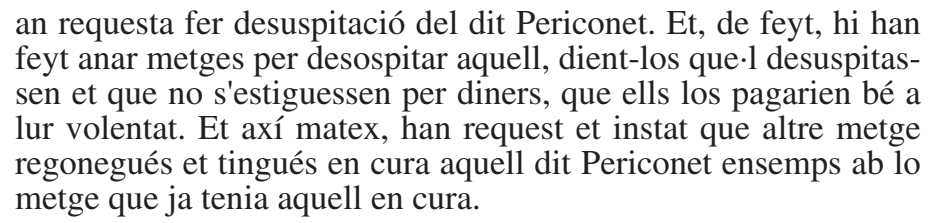

Les quatre declaracions del lleuder, l'escolà, la mossa i la dona del llaurador són l'argument determinant sobre el qual descansa l'acusació. Sense elles, tot no hauria passat de la mera presumpció.

Demostrar la innocència dels acusats es presenta una tasca ben complicada per a Bartomeu Cerdà. No sols té enfront quatre testimonis difícils de rebatre, sinó tota una muralla mental de suspicàcies envers un jueu, poc o gens inserit en les trames de la sociabilitat urbana, i d'indignació barrejada amb temor pel ser la víctima un pobre nen de sis anys. La línia de la defensa es desglossa bàsicament en dues direccions. En primer lloc, Mossé i Salomó, en contra del que ha argüit l'acusació, són dos bons treballadors que viuen del seu ofici de cosir sense fer mal a ningú, i així són reputats per jueus i cristians. Els testimonis ho ratifiquen, per bé que la imatge de Mossé ix més reforçada que la de Salomó. I en segon lloc, Cerdà vol demostrar que en realitat es tractà d'un accident. De la teulada de la casa on viu la parella de sastres caigué una teula que ferí Periconet. Comptat i debatut, totes les teulades del carrer estaven somogudes, trencades o mig partides a causa de l'apedregada del Divendres Sant, en special -assegura Domingo Castell- les teules exints fora la carrera en e per les quals les aygües pluvials deguoten o sollen. Bastà una mica de 
vent, com el que féu l'endemà, o el moviment d'algun gat o ocell, perquè un tros de teula es precipités avall. Francesca, la dona de Domingo Castell, veïna de Mossé i Tudelli, diu que és ver que no era gran lo dit vent, però no obstant això caigueren moltes teules. Tant és així, que ella

e una juhia se rahonaven dient la juhia a ella... si serien amichs d'ací avant, e ella... respòs a la juhia et dix que li plahia. E mentre que.s rahonaven, un pardal posàs en una teula d'aqueles que eren stades trencades e somogudes lo dia del Divendres Sant e caygué e donà en terra entre abdues, e si donat los hagués a la una o l'altra les hagra mortes ${ }^{40}$.

Domingo, el seu marit, va més enllà encara. Amb els seus propis ulls va veure com queia un tros de teula que pegava al cap d'un fadrí cristià, és a dir, Periconet, mentre els jueus eren dins casa, puix que per la pahor del dia de Divendres Sant proppassat ningun juheu gosava exir a les portes ni en la carrera ni mirar per les finestres. Amb tot, no sap de certa sciència si la féu caure lo vent o pardal que s'i posà o altri qui la lançàs, com tant solament ves aquella caure de la dita teulada.

¿Tan gran fou, però, l'harca dels cristians? Bartomeu Cerdà informa que el cendemà del Divendres Sant, fon atrobat que jahien en la dita carrera dels dits juheus passades $V$ càrregues de pedres codices, axí mandronals com altres e codices e teules trencades. Entorn, doncs, dels 600 quilos. El terra degué quedar literalment sembrat de pedres ${ }^{41}$. Domingo Castell calcula entre cinc i sis càrregues, les mateixes que Pasquala la tendera, mentre que Francesca, la dona de Castell, n'avalua set. Tots tres coincideixen en la recollida el mateix dia a càrrec d'un hom ab un rocí per abocar-les a la rambla. Jafudà Façan hi afegeix que cobrà dos diners per cascuna càrrega. L'aljama els hi degué pagar. Dit d'una altra manera, l'aljama ja tenia previst l'apedregada i la recollida. Aquests arravataments impulsius estaven incrustats en les inèrcies fervoroses de la Setmana Santa al llarg i ample de la geografia de l'Occident medieval. Dijous i Divendres Sant s'havia de recordar contundentment als jueus la mort que infligiren a Jesucrist, i una de les formes que s'universalitzà fou la de llançar-los pedres. Convenia, doncs, tancar-se durant aquests dies en casa i no exposar-se a la fúria ritual d'uns cristians esbravats per una fe combativa, sota els estímuls de vegades de la ingesta excessiva de vi. Mossé

${ }^{40}$ Magnífic testimoni sobre les xarxes d'amistats interconfessionals, al marge de la seua validesa en suport de les tesis de la defensa.

${ }^{41}$ Les pedres "codices" són còdols o palets de riera, i les mandronals -mot no recollit al diccionari Alcover-Moll-, són pedres de mandró, de fona. Na Pasquala en diu pedres "codices mandronals tiradices". La càrrega valenciana equival a 127,80 kg. Vegeu C. Alsina, G. Feliu, L. Marquet, Pesos, p. 134 
Tudelli s'estigué d'eixir el Dijous Sant a portar unes robes al seu col-lega Ramon Rovira que havia cosit per al tresorer del marquès de Villena, tot $\mathrm{i}$ fer-li-les arribar per mitjà d'un altre: mas veu-diu Rovira-que per ço que negun no li fes negun enuig ni ell a altri, no volgué venir lo Dijous de la Cena a casa d'ell..., ans lo dit Mossé li tramés a ell..., les dites robes del dit tresorer. L'endemà, desfogats els ànims, el riu de la normalitat quotidiana tornava a mare ${ }^{42}$. A València l'harca es perpetrava si més no des de 1287 , des que es té constància documental. La protecció reial de poc servia i invariablement es repetia cada any amb l'arribada de la Quaresma. L'aljama assumí el paper pacient d'una representació infame. Guillem Llonc és sastre, ha cosit des de fa més de vuit anys amb Mossé Tudelli, però això no trau que alguna vegada s'hi haja immiscit en l'harca i, tal com reconeix la seua dona Benvinguda, quan los yva desonrar ells-Tudelli i Arroti-s'ó sofferien e ç'ó comportaven bé. Segons les circumstàncies, determinades per les convulsions de la política local, o les maltempsades d'una pesta, fam o carestia, podien involucrar-se artesans i fins i tot generosos i patricis locals. Però el protagonisme l'assumien els joves i infants. Bernat Guerau, l'escriptor, que el dia de Pasqua estigué en casa de Mossé Tudelli i Salomó Arrotí rahonant-se amb les muller de aquells, bé sap que el dia anterior plogueren pedres, per ço com ell... era infant poch appedregava als dits juheus no solament en lo Divendres Sant e vespra de Pascua ans en lo dia de Paschua hi apedregàs ell..., e creu que axí matex ho facen ara los dits fadrins. I un dels que intervingueren Divendres fou ni més ni menys que el mateix mosso del justícia criminal ${ }^{43}$. Ara bé, aquesta bel-ligerància pasqual no és compartida per tothom. N'hi ha que comprenien l'absurditat d'aquesta violència supèrflua. Domingo Castell, davant els grans crits que los dits juheus cridaven per lo dit apedregament... muntà dalt en lo terrat e féu cessar a alguns que no fessen tant de mal com volien fer ${ }^{44}$.

Ara cada part té còpia dels testimonis de l'altra. Els procuradors les llegiran atentament per a rebatre'ls. El 7 de maig, dilluns, un saig, de manament de Miquel Just, el lloctinent del justícia, i a instància de Pere Llàtzer, mana a Bartomeu Cerdà que per a dimecres presente les al-legacions oportunes en deffensió dels dits denunciats. No ho farà sinó fins dijous, després que Llàtzer li acuse la corresponent contumàcia. Cerdà demana el rebuig dels testimonis que han declarat de auditu, sense haver-hi vist res, e testimoni de

${ }^{42}$ Sobre aquesta violència ritual vegeu R. Girard, La violence; D. Nirenberg, Communities; A. Toaff, Il vino, pp. 223-225.

${ }^{43}$ Identificat pel peller Joan Borràs, qui veié "un moço del justícia criminal tirant-los moltes e diverses pedres per fer mal als dits juheus, axí sobre les teulades com en lo carrer e a les portes dels juheus o lla on s'esdevendrà".

${ }^{44}$ A Domingo Castell, cal reconèixer, també li feien pols la teulada. Hom podria al-legar-hi que era part interessada. 
hoïda no val segons Furs ${ }^{45}$. Els de Francesca, dona de Pere Rabassa, i el de na Suau també, cal no admetre'ls perquè són fembres, e de fur és clar e indubit que en fet criminal fembra no fa testimoni, a més de deposar d'oïda. El de Joana, la muller del llaurador Joan Garcia, és de dona i cau en flagrants contradiccions. I declara falsedats, ja que venint des del carrer de Sant Tomàs, en la seua confluència amb el de Fabra, que és a travers et és carrer estret, és impossible veure ningú a la finestra al final d'aquest carrer de Fabra, a tocar ja de Sant Joan de l'Hospital, considerada la distància que ha del cap del carrer tro a la casa on stan los dits juheus, e considerada la stretura del cap del carrer per on passava la dita dona, com en passant, en menys de tres passes, sie reclòs e transpost lo dit carrer on stan los dits juheus. Joana, conclou Cerdà, és dona de pocha consciència e de pocha fe. Pel que fa a Tomasa, com que és dona i només té 13 anys no pot testificar, mentre que Guillem Francesc i Gabriel Amat, ambdós han fet declaracions discordants. El lleuder, adverteix Bartomeu Cerdà, és hom fort voluntari e no guardant dret ni rahó, e no fa ni diu sinó ço que ve a la volentat desordenadament, e és hom que.s torba de volenters e quasi tots dies, e hom de mala fama e conversació, e que no guarda ni guardaria religió de sagrament... e és monçoneguer, falsiós e viciós de mals vicis. Unes acusacions que Cerdà, però, no demostra amb fets. Finalment diu de Gabriel Amat que és menor de 15 anys, i potser de 14, i malvolent mortal dels dits juheus, e poch temps ha que amb un punyal treyt en la mà los atacava per matar-los, e volia encara muntar en la casa d'aquells per occir-los; sinó que s'i meteren, e•ls ha en gran hoy. Es referia, sens dubte, a la baralla que tingué amb el mateix Salomó Arroti, convenientment amplificada per Cerdà.

Pere Llàtzer, en canvi, no recusa cap testimoni dels acusats, llevat d'al-legar-hi que no deposen sinó de hoïda. Es limita a insistir en la culpabilitat d'un dels dos acusats, a partir de les declaracions de Guillem Francesc, Gabriel Amat, Joana i Tomasa; de les paraules que Clara digué a na Suau, en què reconeixia allò de que mala ventura fon de mon marit que li scapà la pedra de la mà stant a la finestra; de l'intent de subornar la tendera per part d'una de les dones, i de la demanda de dessospitació. Tanca la seua exposició demanant que, tot i les proves, Mossé Tudelli i Salomó Arroti siguen turmentats "tant e longament fins que de la pròpria bocha d'aquells sia sabuda la veritat del feyt.

\footnotetext{
${ }^{45}$ Es refereix a Bartomeu Vilanova, Pere Rabassa, Joan Borràs -que també testimonia en el torn de la defensa-, Lluís de Menargues, Bartomeu de Vilalba, Jaume Alfonso, Antoni Mateu, Arnau de Pisa i Pere Escrivà.
} 


\section{TURMENTS I SENTÈNCIA}

El 21 de maig es reuneix el Consell de la ciutat de València. El justícia criminal, requerit per Pere Llàtzer, puja alt a la Sala, acompanyat pel lloctinent i l'escrivà, on té lloc la sessió. A Salomó Arroti de la presó comuna l'han traslladat deval la Sala, on dos saigs per torns el custodiaran durant cinc dies. Davant els jurats i els prohoms, Joan de Quintavall fa una llarga i meticulosa exposició del cas. En acabar, el Consell concordantment manà que lo dit Salamó Aroti, lo qual aparia que agués feta la dita mort del dit Periconet... fos muntat en la Sala e que aquell fos passat a qüestió de turments fins que confessés la veritat. Abans, però, el justícia pronuncia la preceptiva interlocutòria de turments, atesos els "indicis e presumpcions" contra Arroti.

Sense cap més dilació, el despullen tot nuhu, en bragues, e ligades les mans detràs. El justícia i l'assessor li demanen que confesse, i com s'entesta a proclamar la seua innocència, li lliguen les mans a la corriola que penja del teginat de la Sala, i comencen els saigs a pujar-lo. Alçat ben amunt, li ho tornen a preguntar. Salomó respon "que plagués a Déu que no y sabia àls sinó ço que confessat havia desús”. E com hagués stat per convenient instància o spay en lo dit turment, el baixen. Ha resistit la primera escomesa ${ }^{46}$. Li demanen una altra vegada la confessió del crim. En negar-lo, el justícia l'amenaça que en altra manera que $s$ seria procehit contra aquell a majors turments e li seria ligada la pedra blava als peus. El dolor als braços i l'espatla devia ser terrible, penjat per les mans lligades darrere i un pes als peus. Així ho fan, i abans de pujar-lo Arroti insisteix que no y sabia res, que bé.l podien trocejar en lo dit turment. Per segona vegada penjant en l'aire, enmig de la Sala del Consell, el justícia li pregunta diverses vegades si ha estat ell qui va llançar la pedra. Arroti respon per fi que no.l tirassen, que dirie la veritat. Però no el baixen fins que ho proclame de viva veu, i llavors respòs e dix que ja Déus no volgués.

Tornen a abaixar-lo, a poc a poc, i com fos a la migania del dit turment, on [fon] interrogat que dixés la veritat, lo qual respòs e dix cridant grans crits que.l devallasen, que.ll dirà la veritat. Ara sí que ho reconeix. Li pregunten la raó per la qual havia llançat la pedra, et dix que lo devallasen, que $l l$ ho diria. I en ser abaixat, ho nega tot. Ni el justícia, ni el lloctinent ni els saigs es desesperen. Són habituals aquesta mena d'ardits. Tard o d'hora confessarà. El justícia manà gitar al dit denunciat en les spalles aygua freda. No es pot fer l'interrogatori sense la plena consciència del reu. Davant una nova negativa, li

46 També deuen estar aplicant-li un suplici d'escalfor als peus, perquè entre les despeses hi ha l'anotació de 2 sous de carbó per al turment. Les cordes - "tronyelles"- en costen un. Als saigs que tiren de la corda els en paguen també un pel beure.

ANUARIO DE Estudios MEdievales, 43/2, julio-diciembre 2013, pp. 577-608 ISSN 0066-5061, doi:10.3989/aem.2013.43.2.03 
lliguen dues pedres als peus. El justícia, pacientment, formula la pregunta. La resposta de Salomó Arroti no pot ser més explícita: si crestià fos el..., que no li farien ço que li fahien. Així que comencen els saigs a estirar, Arroti prega que s'aturen. Desesperat, com a últim recurs, imputa la pedrada a hun fadrí, germà de la muller del dit Mosé Tudeli. Bé que ho sap per ço com ell ho veu a hul. Devia tenir l'esperança que, per ser menor d'edat, no seria condemnat a mort ${ }^{47}$. No s'ho creuen, perquè a casa no hi havia més que ell i Tudelli amb les dones $\mathrm{i}$ els fills. Els saigs tiren de la corda: en són necessaris dotze, tal és pes de les dues pedres $^{48}$. Salomó, retut, s'apressa a admetre-ho, ço és, que lo dit dia... ell... e sa muller scombraven casa, e que ell... havia presa una pedra que havia trobada en la carrera i la llançà per la finestra no pensant o cuydant que ningú agués en la dita carrera. Li pregunten si havia vist Periconet, i diu que no. Tampoc s'ho creuen i el justícia requereix als saigs de tirar una altra vegada. Per fi, Salomó confessa que ver era e cert que.ll... havia tirada la dita pedra al dit Periconet de certa sciència, e que havia vist aquell bé en la carrera com tirà la dita pedra. Volen saber, a més, si els altres eren stats consents en lo tirar de la dita pedra, $e$ dix que no. Era ver, emperò, que.ll... ac tirada la dita pedra al dit Periconet ho avia dit als altres denunciats, los quals li digueren que bé avia fet. Els saigs el deslliguen, el vesteixen, el duen a la cambra nova de la Sala del Consell, separat del turment, i ací, el tornen a interrogar i persevera en la confessió. El justícia ha aconseguit al capdavall que Arroti confessés el que volia que confessés. Ací rau l'eficàcia del turment. De seguida, Joan de Quintavall i Miquel Just fan relació al Consell de tot el que s'ha esdevingut durant el turment. Els prohoms i representants de la ciutat no dubten un instant, i unànimement proposen al justícia que lo dit Salamó Aroti fos condemnat e deliurat a mort, ço és, que li fos tolt lo puny dret en aquell loch on nafrà e ferí lo dit Periconet, e en aprés que fos penjat per los peus e apedregat en manera que morís, a més de pagar les despeses del procés. El justícia abaixa de la Sala i, present Pere Esteve, el pare, promulga la sentència en els mateixos termes que el Consell.

$\mathrm{Al}$ cap de cinc dies té lloc l'ajusticiament, anunciat pels llocs acostumats de València per en Serrador, el trompeta ${ }^{49}$. Onze saigs porten Salomó des de la Sala del Consell fins al carrer de Fabra. Ací, Bernat Nicolau, el botxí, li

\footnotetext{
47 Però Pere el Cerimoniós confirmà, l'any 1371, una sentencia de mort dictada pel salmedina de Saragossa i apel-lada al justícia d'Aragó, contra un menor d'edat, atès que posseïa discreció suficient per a matar junt amb el seu pare, penjat ja per la forca, un cristià en un camí públic. J. Riera, Penjar pels peus, p. 613.

${ }^{48}$ Cadascun cobrarà 2 sous. Potser no tirarien tots a l'hora i ho farien per torns. Però evidentment calia la força de diversos homes per aixecar el pes de l'home i el de les pedres. Arroti n'ha resistit dues, però n'hi ha que li'n posaven tres: la pedra habitual, la blava i la verda.

${ }^{49}$ No hi ha la data ni cap referència a l'ajusticiament, però Arroti ha estat "guardat" davall la Sala durant cinc dies per dos saigs, a raó de 3 sous el dia.
} 
lleva el puny ${ }^{50}$. Les pedrades mortals, les tiren els veïns de la ciutat que voldran. L'execució és fa llarga, ha durat més de mig dia ${ }^{51}$.

Últim serrell: pagar les costes. Pere Llàtzer les presenta una setmana després del veredicte. Els 4.802 sous reclamants adverteixen que la venjança contra el jueu s'ha convertit ara en una extorsió descarada. Els advocats - misser Ramon Tolosa i misser Ponç Savartès-, un per cada part, que no hi han figurat per a res, ara apareixen per a destinar-los a cada un 1.100 sous, o cent florins, com lo procés sia stat fort maliciós e de grans afanys, exactament el mateix que cada procurador, també perquè han haüts grans afanyhis. Llàtzer xifra en 200 sous la despesa en escriptures, una quantitat enorme ben difícil de justificar ${ }^{52}$. Cerdà s'hi oposa, el justícia hi persevera. Salomó i Clara no posseïen béns per valor de gairebé cinc mil sous. ¿Qui els pagaria, doncs, si és que es van poder pagar? ${ }^{53}$

Exactament en dos mesos i mig, Salomó Arroti ha estat inculpat, processat $\mathrm{i}$ executat. Poques vegades la justícia es mostrava tan ràpida i expeditiva. La morositat, la lentitud, sovint causada per les intervencions capcioses de procuradors i advocats, que es mereixen el blasme de moralistes com Francesc Eiximenis, és el que caracteritza, en canvi, el funcionament dels tribunals. La infantesa de Periconet, en sacsejar les consciències i les emocions dels jutges i els prohoms, ha precipitat els mecanismes eficients de la justícia, tant com la manca de béns del jove sastre Salomó Arroti per dilatar mitjançant recursos i apel-lacions el procés. La justícia opera així, de manera diferent segons els nivells socials i la categoria de l'acusat. Hi ha una selecció econòmica que aboca els pobres a la duresa fulminant de la $1 e^{54}$. Per a qui no pot pagar -o "comprar" jutges, testimonis i fins els mateixos carcellers-, l'acció de la justícia és inexorable, urgent, severa i brutal. Per a qui pot pagar, en canvi, la justícia és més flexible i condescendent. La confessionalitat del presumpte culpable -i sempre sobre Arroti penjarà la

${ }^{50}$ El trompeta i el botxí cobren 5 sous cadascun.

${ }^{51}$ Així consta en la llista de les despeses: els saigs "qui anaren a fer la execució del dit Salamó, com fos més de mig dia" cobraren un sou i mig cada un, un total, doncs, de setze sous i mig. Penjar pels peus és, segons Jaume Riera, la pena de mort ordinària aplicada als jueus $i$ musulmans per delictes comuns. J. Riera, Penjar pels peus, p. 609. El 1386, sis anys després de l'execució de Salomó Arroti, Pere el Cerimoniós concedeix a l'aljama de València el privilegi d'abolició de l'apedregada i la burxa amb canyes per part dels assistents al suplici. Així que els jueus condemnats eren elevats per morir cap per avall, lentament en una llarg agonia, els cristians començaven a apedregar-los i fustigar-los amb canyes. Ibidem, p. 617.

${ }^{52} \mathrm{La}$ resta es reparteixen entre els saigs, per diferents tasques de custòdia dels inculpats turments de Salomó, el carbó i les cordes per als turments, el trompeta i el botxí.

${ }^{53}$ Una part, però ben minsa, degué provenir segurament del béns mobles inventariats de la casa on vivia el matrimoni. Una casa llogada, no en propietat. Malauradament l'inventari no va ser adjuntat al procés.

${ }^{54}$ R. Narbona, Malhechores, pp. 163-170. 
presumpció d'innocència, perquè sols va confessar per mitjà del turment- ha accelerat encara més el desenvolupament de la causa. Paga la pena de recordar una vegada més la queixa de Salomó: si cristià fos ell, que no li farien ço que li fahien. Tenia raó. No perquè als cristians no els turmentassen, sinó perquè l'estigma hebreu d'entrada ja era un agreujant. La part vencedora aprofita la sentència per a dur a terme una depredació legalitzada, en connivència amb els jutges. La ciutat, per part seua, ho aprofita per a refermar la seua autoritat contra els delinquients mitjançant el terror i proporcionar, de passada, un espectacle, edificant i terrible alhora, amb què l'esbravar les tensions dels subalterns.

\section{BIBLIOGRAFIA CITADA}

Alsina, Claudi; Feliu, Gabriel, Marquet, Lluís, Pesos, mides i mesures dels Països Catalans, Barcelona, Curial, 1990.

Bramon, Dolors, Contra moros i jueus, València, Tres i Quatre 1981.

Ferragud, Carmel, El naixement d'una vila rural valenciana. Cocentaina, 1245-1304, València, Publicacions de la Universitat de València, 1998.

Ferragud, Carmel, El metge sota sospita. Actuació mèdica en els testimonis pericials a ferits davant la cort del justícia criminal de la ciutat de València (1396), "Recerques" 62 (2011), pp. 69-94.

Furió, Antoni, Garcia-Oliver, Ferran, The horitzons of the city: rural mobility in a frontier land (the Valencian Country, 1250-1350), en Carocci, Sandro (ed.), La mobilità sociale nel Medioevo, Roma, École Française de Rome, 2010, pp. 513-554.

Gallent, Mercedes, Precedentes medievales de la medicina legal: la dessospitació en el Reino de Valencia, "Saitabi" 50 (2000), pp. 11-28.

Garcia-Oliver, Ferran, Jueus contra la norma, o els fracassos de la segregació, "Afers" 27/73 (2012), pp. 535-563.

Girard, Ricard, La violence et le sacre, París, Grassete, 1972

Hinojosa, José, La comunidad hebrea de Valencia: dels esplendor a la nada (1377-1391), "Saitabi”" 31 (1981), pp. 47-72.

Hinojosa, José, En el nombre de Yahveh. La judería de Valencia en la Edad Media, València, Ajuntament de València, 2007.

McVaugh, M.R., Medicine before the plague. Practitionners and their patients in the Crown of Aragon (1285-1345), Cambridge, Cambridge University Press, 1993.

Narbona, Rafael, El justícia criminal. Una corte medieval, un procedimiento judicial, "Estudis Castellonencs" 3 (1986), pp. 287-370. 
Narbona, Rafael, Malhechores, violencia y justicia ciudadana en la Valencia bajomedieval, València, Ajuntament de València, 1990

Narbona, Rafael, Pueblo, poder y sexo. Valencia medieval (1306-1420), València, Diputació de València, 1992.

Narbona, Rafael, El trienio negro: Valencia, 1389-1391. Turbulencias coetáneas al asalto de la judería, "En la España medieval" 35 (2012), pp. 177-210.

Navarro, Germán, Política y avecindamientos. Análisis de la emigración aragonesa a Valencia (1308-1426), en Demografía y sociedad en la España bajomedieval, Saragossa, Universidad de Zaragoza, 2002, pp. 97-128.

Nirenberg, David, Communities of Violence: Persecution of Minorities in the Middle Agges, Princeton, University Press, 1966

Pérez García, Pablo, La comparsa de los malhechores. Valencia 1479-1518, València, Diputació de València, 1990.

Riera, Jaume, Penjar pels peus, en Cristianos y judios en contacto en la Edad Media: polémica, conversión, dinero y convivencia, Lleida, Milenio, 2009, pp.605-622.

Roca Traver, Francisco, El justicia de Valencia, 1238-1321, València, Ajuntament de València, 1970.

Rodrigo Pertegás, José, La judería de Valencia, València, F. Vives Mora, 1913.

Rubio Vela, Agustín, L'escrivania municipal de València als segles XIV i XV: burocràcia, política i cultura, València, Consell Valencià de Cultura, 1995.

Toaff, Ariel, Il vino e la carne. Una comunità ebraica nel Medioevo, Bolonya, Il Mulino, 1989.

Viciano, Pau, Violencia y Sociedad en un villa medieval. Castellón de la Plana en el siglo XV, "Hispania" 61 (2006), pp. 851-882.

Vidal, Pere, Els jueus dels antics comtats de Rosselló $i$ Cerdanya, "Calls" 2 (1987), pp. 56-57.

Fecha de recepción del artículo: junio 2012

Fecha de aceptación y versión final: diciembre 2012 